\title{
Peran Interaksi Simbolik dalam Perencanaan Komunikasi Pemasaran BRE Global (Studi Kasus BRE Global Edukasi dan Karir)
}

\author{
Ivan Sebastian, Muhammad Adi Pribadi \\ sebastian13.ivan@gmail.com, adip@fikom.untar.ac.id \\ Fakultas Ilmu Komunikasi Universitas Tarumanagara
}

\begin{abstract}
The large number of unemployed in Indonesia was mostly dominated by high school graduate and a university graduate. The government also encourages various breakthroughs, one of which is conducting training (training) or internships (internship) to improve human resources and employment. PT.BRE Global Education and career is a consultant engaged in the field of education, where the consultants will help find a way out and provide advice to prospective candidates who want to go abroad either to study or work through training and learning programs owned by companies through social media such as Facebook and Whatsapp as communication media. The author uses a qualitative methodology with strategies and case studies in this research. The purpose of this report is to find out and see how Symbolic Interactions play a role in marketing communication planning carried out by Educational Consultants from PT.BRE Global Education and Careers and the conclusions of this research BRE Global uses 4 stages in its marketing communication planning namely advertising, promotion, sales direct and interactive marketing through the media carried out between consultants and clients and then added to the 5 communication plans starting from Business Objectives, Strategy, Tactical, Monitoring where all stages contain Symbolic Interactions.
\end{abstract}

Keywords: bre global education and career, case studies, marketing communications, symbolic interactionism

\begin{abstract}
Abstrak
Besarnya jumlah pengangguran di Indonesia sebagian besar didominasi oleh lulusan SMK, lulusan SMA, dan lulusan universitas. Pemerintah pun mendorong berbagai terobosan, salah satunya adalah melakukan pelatihan (training) atau magang (intership) untuk meningkatkan sumber daya manusia dan ketenaga kerjaan. PT.BRE Global Edukasi dan karir merupakan konsultan yang bergerak di bidang edukasi, dimana para konsultan akan membantu mencari jalan keluar dan memberikan saran kepada para calon kandidat yang ingin pergi ke luar negeri baik untuk belajar atau pun bekerja. Perusahaan memberikan program pelatihan dan pembelajaran melalui media sosial seperti Facebook dan Whatsapp sebagai media komunikasi. Penulis menggunakan metodologi kualitatif dengan strategi dan studi kasus dalam penelitian ini. Tujuan dari laporan ini adalah untuk mengetahui dan melihat bagaimana interaksi simbolik berperan dalam perencanaan komunikasi pemasaran yang dilakukan oleh Konsultan Edukasi dari PT.BRE Global Edukasi dan Karir. Kesimpulan dari penelitian ini BRE Global menggunakan empat tahapan dalam perencanaan komunikasi pemasarannya yaitu periklanan, promosi, penjualan langsung dan pemasaran interaktif melalui media yang dilakukan antara konsultan dengan klien lalu di tambah dengan 5 perencanaan komunikasi dimulai dari Tujuan Bisnis, Strategi, Taktis, Monitoring dimana seluruh tahapannya mengandung Interaksi Simbolik.
\end{abstract}

Kata Kunci: bre global edukasi dan karir, interaksi simbolik, komunikasi pemasaran, studi kasus 


\section{Pendahuluan}

Indonesia merupakan negara dengan jumlah penduduk terpadat keempat di dunia dengan lapangan pekerjaan yang sangat terbatas, sehingga banyak ditemukan berbagai kasus kesenjangan sosial seperti pengangguran yang disebabkan oleh berbagai faktor. Salah satu faktor yang dapat kita ambil adalah dampak dari berlakunya Masyarakat Ekonomi Asean (MEA) di mana masyarakat lokal diharuskan untuk bersaing dengan tenaga kerja asing yang datang ke Indonesia, karena dengan adanya perekrutan karyawan asing memiliki dampak seperti berkurangnya lapangan pekerjaan untuk masyarakat lokal. Hal tersebut menyebabkan masyarakat Indonesia diharuskan memiliki keterampilan dan kualitas untuk bersaing dengan masyarakat dari luar (blog.ruangguru.com, 2018).

Menteri Perencanaan Pembangunan Nasional Bambang Brojonegoro menilai ada yang salah dengan sistem pendidikan Sekolah Menengah Kejuruan (SMK) Indonesia karena pada dasarnya lulusan SMK diharapkan dapat langsung bekerja setelah lulus, Namun pada kenyataannya ditemukan bahwa lulusan SMK tidak sesuai dengan kebutuhan kerja saat ini karena berupa semi-skill. Pemerintah pun melakukan terobosan dengan memfokuskan revitalisasi kurikulum pendidikan pada kebutuhan industri saat ini. Ditambah dengan Menteri Tenaga Kerja (Menaker) Hanif Dhakiri juga melihat pentingnya memperbaiki akses dan mutu vokasional pelatihan baik teori maupun praktek bagi siswa SMK.

Untuk bekerja di luar negeri, tentu banyak syarat yang harus dipenuhi. Salah satu contoh yang dapat kita ambil yaitu negara Singapura. Peraturan dari Singapura sangat ketat dan dapat berubah sewaktu-waktu, salah satunya yang tertulis di website kementrian pekerja (Ministry of Manpower) "mom.gov.sg", di mana harus memiliki gelar pendidikan dan sertifikat keahlian atau professional. Ditambah lagi dengan berlakunya MEA, setiap negara akan memprioritaskan masyarakat lokal.

BRE Global Edukasi dan Karir adalah perusahaan yang merekrut orang yang berminat untuk belajar atau bekerja ke luar negeri, terutama Singapura. Program belajar yang ditawarkan melalui kerja sama dengan sekolah-sekolah yang di Singapura sehingga memiliki program intership (magang) yang kemudian setelah lulus dapat dilanjutkan dengan kontrak kerja. Pemasaran dilakukan melalui media sosial Facebook yang kemudian dialokasikan ke aplikasi Whatsapp karena aplikasi tersebut merupakan salah satu media komunikasi yang dapat diakses oleh berbagai negara serta penggunaannya yang cukup sederhana. Dalam proses pemasaran program yang dilakukan oleh BRE Global di jalankan oleh para konsultan edukasi yang sudah mengenal baik bagaimana program itu bekerja dan apa yang harus diberikan kepada calon kandidat tergantung pada latar belakang mereka seperti nama, usia, asal mereka/nasionalisme, tingkat Pendidikan, pekerjaan sebelumnya hingga alasan mereka ingin bekerja di Singapura dan semua hal ini dilakukan melalui komunikasi yang bersifat membangun ikatan antara konsultan dengan calon kandidat.

Dalam hal ini, sebagai seorang konsultan penulis diharuskan memahami cara komunikasi, budaya, dan kondisi calon kandidat yang ingin bekerja ke Singapura dari berbagai negara selain Indonesia seperti Filipina, India, Malaysia, Vietnam dan Myanmar. Dengan melalui komunikasi yang terjadi melalui media Whatsapp dimana penulis tidak hanya sekedar memberikan pertanyaan tetapi juga berusaha melakukan proses komunikasi dengan bahasa inggris dengan tujuan memunculkan rasa percaya yang bisa mereka dapatkan dari calon kandidat dengan membangun sebuah ikatan atau yang biasa disebut dengan Bonding karena pemasaran yang dilakukan melalui media 
online sehingga dibutuhkan rasa percaya dan aman antara konsultan dan calon kandidat.

Sebelumnya teknik komunikasi pemasaran yang dilakukan oleh BRE Global Education and Career pada awalnya hanya mengikuti sebuah arahan dari atasan dengan menggunakan Template yang sudah di sediakan dari awal para konsultan bergabung dalam perusahaan, sehingga pola komunikasi yang di lakukan termasuk monoton dan hal ini dapat membuat calon kandidat tidak memiliki rasa percaya ataupun nyaman dikarenakan jenis pertanyaan dan jawaban yang diberikan merupakan kalimat yang sama, sehingga sulit munculnya bonding diantara kedua belah pihak walau sudah melalukan komunikasi 2 arah yang jelas melalui media, bahkan tidak sedikit calon kandidat yang tidak mau melanjutkan komunikasi karena mereka merasa itu merupakan hal yang sia-sia.

Maka dari itu komunikasi pemasaran dalam BRE Global Education and Career saat ini telah diubah kedalam bentuk komunikasi yang lebih terbuka dan bebas, sehingga konsultan dapat melakukan interaksi yang lebih bebas sekaligus leluasa agar calon kandidat dapat merasakan pelayanan yang lebih baik, pada saat teknik komunikasi yang dibawakan sudah tidak monoton calon kandidat tentu merasa lebih nyaman dan percaya untuk menceritakan masalah mereka kepada konsultan dan disanalah akan timbul sebuah penyelesaian melalui program yang sudah disediakan sekaligus terciptanya ikatan antara konsultan dan calon kandidat (bonding).

\section{Metode Penelitian}

Dalam penelitian, Penulis menggunakan metode penelitian kualitatif sebagai metode pendekatannya. Di dalam buku Metodologi Penelitian Kualitatif, menurut Moleong penelitian kualitatif dapat di definisikan sebagai sebuah penelitian yang bertujuan untuk lebih mengerti dan memahami fenomena yang dialami oleh subjek penelitian yang di dalamnya mencakup motivasi, persepsi, perilaku, dan tindakan yang setelah itu di deskripsikan dalam bentuk kata-kata pada konteks tertentu dengan menggunakan metode alamiah.

Peneliti menggunakan metode studi kasus dimana studi kasus dapat memberi nilai tambah pada pengetahuan penulis dan banyak orang mengenai fenomena individual, organisasi, sosial dan politik. Secara singkat penelitian studi kasus bertujuan untuk membantu peneliti dalam mempertahankan karakteristik holistik dan mempunyai makna dari kejadian-kejadian nyata misalnya seperti kehidupan seseorang, proses berjalannya suatu organisasi dan manajemennya, perubahan lingkungan sosial, hubungan-hubungan internasional, dan kematangan industri. (Yin, 2013).

Subjek yang di teliti ini adalah narasumber yang dapat memberikan informasi terhadap masalah yang sedang diteliti oleh peneliti. Subjek tersebut juga merupakan orang-orang yang memiliki ikatan dengan objek penelitian ini. Narasumber harus memberikan informasi yang jelas dan akurat kepada peneliti agar peneliti dapat membuahkan hasil penelitian yang sesuai dengan apa yang di harapkan. Subjek yang diteliti yaitu para pihak yang terlibat didalam BRE Global dan untuk objek dalam penelitian ini adalah Perusahaan PT.BRE Global Edukasi dan Karir, dimana seluruh kegiatan pemasaran dilakukan. 


\section{Hasil Penemuan dan Diskusi}

Berdasarkan data yang didapat oleh penulis pada saat melakukan penyelesaian tugas akhir, BRE Global merupakan salah satu perusahaan yang menjadi bagian dari konsep Generalized Others yang di jelaskan oleh Mead. Dikarenakan BRE Global mengikuti peraturan yang di buat oleh pemerintah mengenai PSBB (Pembatasan Sosial Berskala Besar) pada masa covid-19. Pembahasan ini berdasarkan hasil dari wawancara mendalam yang dilakukan oleh penulis terhadap informan yang sangat erat kaitannya dalam Perencanaan Komunikasi Pemasaran BRE Global yang kemudian dikaitkan dengan teori Interaksi Simbolik dan Teori Komunikasi Pemasaran. Berdasarkan yang tertera pada bagian visi dan visi perusahaan, BRE Global telah memenuhi syarat untuk menjadi bagian dari Particular Others namun dikarenakan adanya Covid-19 yang saat ini berada dalam Society maka BRE Global mengambil langkah untuk menghentikan operasional kantor untuk sementara mengikuti peraturan dan arahan pemerintah. Karena jika BRE Global masih beroperasi tentu akan menjadi masalah yang artinya menentang aturan pemerintah, ditambah lagi dengan adanya kondisi lockdown.

\section{Perencanaan Komunikasi Pemasaran}

Dalam penelitian ini, penulis meninjau keterkaitan dan peran dari Interaksi simbolik dengan Perencanaan Komunikasi Pemasaran yang ada di BRE Global melalui 4 tahapan yaitu Periklanan (Advertising), Promosi (Promotion), Pemasaran Langsung (Direct Marketing), dan Pemasaran Interaktif (Interactive Marketing) dari sebelum hingga selama masa Pandemi berlangsung

\section{Tujuan Bisnis}

BRE Global melihat bahwa kebanyakan dari warga Indonesia pasti ingin memiliki karir yang lebih baik di Singapura mulai dari pendidikan atau kesempatan kerja yang bisa mereka dapatkan melalui program magang dimana mereka perlu menunjukkan bahwa mereka memiliki peforma yang baik sehingga mereka dapat mendapatkan karir yang baik di Singapura.

\section{Strategi}

Adanya perbedaan antar suku, budaya dan ras tetapi perusahaan tetap diharuskan menggunakan bahasa Inggris yang sifatnya universal, dan para konsultan pun diharuskan menggunakan bahasa Inggris dalam memberikan pelayanan yang layak kepada inquiry. Hal itu sudah menjadi aturan dari perusahaan dimana konsultan harus memiliki rasa toleransi dan fokus terhadap komunikasi yang dilakukan dengan orang-orang dari berbagai macam negara walau dengan bahasa Inggris yang kurang fasih. Hal ini dikaitkan dengan pada teori Interaksi Simbolik pada bagian Mind (Pikiran). Dengan adanya sebuah makna yang berbentuk good-service dalam artian penggunaan bahasa agar kedua individu dapat mengerti satu sama lain.

\section{Taktis}

Taktis dalam sebuah perencanaan berdampak besar karena dalam bagian ini. Taktis akan menjadi penentu dalam pengambilan kesimpulan sekaligus menjadi 
rincian pemasaran dan di dalamnya terdiri dari Periklanan (Advertising). BRE Global memiliki media sosial berupa Facebook dan Instagram yang berfungsi untuk periklanan terhadap produk yang berupa pelayanan jasa untuk edukasi dan magang keluar negeri. Berikutnya promosi (Promotion) yang saat ini dilakukan oleh BRE Global menggunakan media sosial seperti Facebook yang pada nantinya jika ada klien yang tertarik akan disambungkan pada media whatsapp, diikuti dengan pemasaran langsung (Direct Marketing) dimana para konsultan mengunjungi sekolah-sekolah atau lembaga pelatihan kerja untuk melakukan presentasi dan yang terakhir adalah pemasaran yang interaktif (Interactive Marketing) BRE Global dilatih untuk menggunakan bahasa yang bersahabat dan harus lebih dominan dalam proses konsultasi yang sedang dilakukan, karena melalui media whatsapp yang artinya klien dan konsultan tidak dapat bertemu secara langsung sehingga selain komunikasi yang baik, dibutuhkan pula pemahaman dan rasa percaya dari pihak klien kepada konsultan.

\section{Monitoring}

Selama masa Pembatasan Sosial Berskala Besar (PSBB) Pandemi Covid-19, banyak perusahaan yang tidak dapat melakukan pemasaran. Sementara BRE Global tetap melakukan pemasaran namun menggunakan cara yang berbeda, yaitu lebih berfokus melakukan pendekatan kepada konsumen dan membangun hubungan baik.

\section{Evaluasi}

Terkait Covid-19 tentu sangat berdampak pada perusahaan tidak hanya pada tingkat atas namun juga pada staf yang bekerja pada perusahaan tersebut. Walau sudah mendapat arahan dari pemerintah di Indonesia untuk melakukan PSBB, para staf masih melakukan pemasaran dengan metode yang berbeda seperti melakukan pendekatan pada pasar dengan cara berkomunikasi dengan klien dan menjaga hubungan baik saja walau tidak dapat mengikuti program pelatihan.

Pembahasan ini berkaitan dengan konsep Particular Others yang terdapat dalam teori Interaksi Simbolik dimana para staf melakukan PSBB dengan bekerja di rumah, tetapi tetap aktif melakukan komunikasi pemasaran.

Gambar 1. Logo BRE Global Edukasi dan Karir

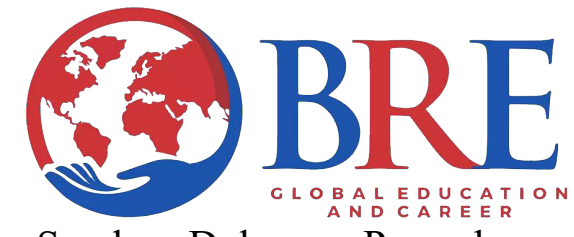

Sumber: Dokumen Perusahaan

\section{Kesimpulan}

Berdasarkan hasil dari penelitian yang sudah dijelaskan di atas, maka kesimpulan yang didapatkan dalam penelitian "Peran Interaksi Simbolik dalam Perencanaan Komunikasi Pemasaran yang dilakukan Oleh Konsultan BRE Global (Studi Kasus BRE Global Edukasi Dan Karir)" yaitu sebagai berikut:

1. Perencanaan komunikasi pemasaran dalam BRE Global terbentuk dari empat konsep dasar dimulai dari Produk dan Merek, Peraturan, Promosi dan Strategi Pemasaran. 
2. Interaksi Simbolik berperan penting dalam Komunikasi Pemasaran yang dilakukan oleh BRE Global karena komunikasi merupakan strategi utama dalam melakukan pemasaran.

3. Interaksi Simbolik berperan penting dalam membangun hubungan yang baik antara atasan dengan staf sekaligus juga antara konsultan dengan klien.

\section{Ucapan Terima Kasih}

Penelitian ini dapat diselesaikan berkat bantuan dan dukungan dari berbagai pihak disekitar penulis. Oleh karena itu, penulis ingin menyampaikan rasa terima kasih kepada seluruh pihak yang sudah ikut terlibat, dan terima kasih kepada seluruh pihak BRE Global yang sudah bersedia untuk di wawancara oleh penulis.

\section{Daftar Pustaka}

Drianny, Yoan. (2020, Mei 24). Wawancara Pribadi.

Gusrilvi, Alfredo. (2020, Mei 26). Wawancara Pribadi.

Kotler Philip, Keller Kevin Lane (2012). Manajemen Pemasaran Terpadu edisi 12. Jakarta: Erlangga

Kwan, Kelly. (2020, Mei 25). Wawancara Pribadi.

Moleong, Lexy. J. (2014). Metode Penelitian Kualitatif, Edisi Revisi. PT Remaja Rosdakarya, Bandung.

Percy, Larry.,Rossiter, John.2012. Strategic Advertising Management. Oxford University Press: New York

Pribadi, M. A., Suganda, Venus, \& Susanto, E. H. (2018). Dinamika Perusahaan Periklanan Indonesia: Studi Kasus Komunikasi dan Budaya Organisasi Dwi Sapta IMC dan Fortune Indonesia. Disertasi Universitas Padjajaran. Bandung: Universitas Padjajaran.

Richard West, \& Lynn H. Turner. (2008). Pengantar Teori Komunikasi: Analisis dan Aplikasi (Buku 1) (Edisi 3). Jakarta: Salemba Humanika

Yin, Robert. K. (2014). Studi Kasus: Desain \& Metode. Rajagrafindo Persada. Jakarta 